\title{
KESERASIAN LAFAZ GAYA BAHASA JINAS DALAM KITAB AL-HIKAM AL-'ATA'IYYAH: KAJIAN NILAI ESTETIKA
}

\author{
Mhd Faizal Mhd Ramli ${ }^{1}$ \\ Pusat Bahasa, Universiti Pertahanan Nasional Malaysia \\ Kem Sungai Besi, 57000 Kuala Lumpur \\ Mohd Sukki Othman² \\ Pabiyah Hajimaming@Toklubok ${ }^{3}$ \\ Jabatan Bahasa Asing, Fakulti Bahasa Moden dan Komunikasi, \\ Universiti Putra Malaysia, 43400 Serdang, Selangor \\ ${ }^{1}$ salsabila.mfaizal@gmail.com \\ ${ }^{2}$ msukki@upm.edu.my \\ 33pabiyah@upm.edu.my
}

\begin{abstract}
Abstrak
Kajian ini memfokuskan kepada keserasian lafaz gaya bahasa jinās dalam kitab alHikam al-'Ata'iyyah. Kitab tersebut dilihat sebagai sebuah karya dakwah yang mempunyai aspek keindahan bahasa dan ketinggian sastera. Justeru, kajian ini menjelaskan nilai estetika gaya bahasa jinās dari sudut keserasian lafaz. Kajian ini dibincangkan dengan menggunakan pendekatan Ali al-Jundi yang meletakkan keserasian lafaz sebagai salah satu daripada kriteria nilai estetika jinās. Hasil kajian membuktikan bahawa penulisan dakwah Syeikh Ibn 'Ata'illah al-Sakandari mempunyai hikmah yang bersifat rabbani dan banyak dipengaruhi oleh kesenian balaghah Arab yang amat tinggi.
\end{abstract}

Kata kunci: jinās, al-Hikam al-'Ata'iyyah, keserasian lafaz, nilai estetika

\author{
SUITABLE PRONUNCIATION OF JINĀS LANGUAGE STYLE IN \\ AL-HIKAM AL-'ATA'IYYAH: THE STUDY OF AESTHETICS VALUE
}

\begin{abstract}
This research focuses on the suitable pronunciation of jinās language style in alHikam al-'Ata'iyyah. The book is regarded as a masterpiece with beautiful language and high level of literature. The objective of the research is to explain the aesthetics values of al-jinas in al-Hikam al-'Ata'iyyah, in the aspect of suitable pronunciation. This research will be discussed using Ali al-Jundi's approach which put suitable
\end{abstract}


pronunciation as one of the aesthetics value of jinās. The result shows that religious writings by Syeikh Ibn 'Ata'illah al-Sakandari illustrates the divinity of Almighty and mostly influenced by the very highest level of Arabic rhetoric art.

Keywords: jinās, al-Hikam al-'Ata'iyyah, suitable pronunciation, aesthetics value

\section{Pendahuluan}

\section{Definisi al-Jinas}

Muhammad ibn Mukarram Ibn Manzur (2003) mendefinisikan al-jinas dengan maksud penyerupaan. Menurutnya, perkataan (الجنس) lebih umum daripada (النوع). Daripada (جَنَنَ) "ja-na-sa" itu, baharulah dipecahkan kepada (يُجَانِنُ) "yu-ja-ni-su”,

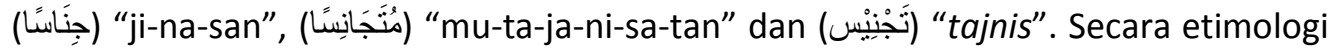
bererti menyerupai dan menyatu bersamanya dalam satu bentuk (Muhammad ibn Mukarram Ibn Manzur, 2003).

Secara istilahnya, Ali al-Jundi (1954) telah menyepakati apa yang didefinisikan oleh Abdallah Ibn al-Mu'taz (1982) tentang jinās dengan maksud mendatangkan perkataan lain yang menyerupai dalam rangkap puisi dan percakapan, dengan kata lain mewujudkan kesamaan pada penulisan hurufnya (Abdallah Ibn al-Mu'taz, 1982). Sementara Ali al-Jarim dan Mustafa Amin (1979) mendefinisikannya dengan maksud penyerupaan dua lafaz pada sebutan, dan berbeza pada maknanya. Menurut Abd al-Qahir al-Jurnani (1988), gaya bahasa jinās atau tajnis adalah dua perkataan yang hampir sama huruf-hurufnya tetapi berbeza maknanya. Sebagai contoh, beliau membawa ungkapan al-Imam al-Syafi'e sewaktu beliau ditanya mengenai hukum al-Nabiz (jus buah anggur yang diproses sehingga memabukkan). Lalu beliau mengatakan:

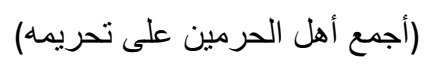

Maksudnya "Telah bersepakat penduduk dua tanah haram di atas pengharamannya".

Dua perkataan yang hampir sama ialah (الحرمين - تحريمه) (Abd al-Qahir alJurnani, 1988, hlm. 8).

Para ulama balaghah berpandangan bahawa jinas mempunyai empat syarat tertentu, antaranya, ia mestilah menyepakati pada bunyi sebutan huruf, penyerupaan hendaklah disaring pada bentuk lafaz, bilangan huruf dan susunannya. Penyerupaan tersebut sama ada secara keseluruhan atau sebahagian tertentu.

Di sini jelas menunjukkan bahawa jinās dari segi istilah lahir daripada maksud jinās dari segi bahasa. Selain itu, maksud jinās secara umum merujuk kepada asas yang sama sebagaimana takrif di atas. Daripada perbincangan di atas dapat dirumuskan bahawa jinas boleh dirujuk di bawah kelompok al-muhassinat allafziyyah, yang terdapat di dalam ilmu al-badi' mengikut pembahagian ilmu balaghah, iaitu penghias lafaz yang mampu menyatakan suatu keindahan dan mengeluarkan rentak bunyian yang menarik. 


\section{Kandungan Kitab al-Hikam al-'Ata'iyyah}

Dari segi bahasa perkataan hikam adalah kata jamak kepada perkataan hikmah yang mempunyai beberapa pengertian. Perkataan "al-hikmah" disebut sebanyak 19 kali di dalam al-Quran adalah perkataan bahasa Arab yang berasal daripada kata kerja hakama. Menurut al-Mu'jam al-Wasit, kata "al-hikmah". Hasil daripada kata kerja hakama tersebut, maka terbitlah perkataan "al-hikmah" yang diertikan sebagai keadilan, ilmu pengetahuan, dan kebijaksanaan. Perkataan "al-hikmah" adalah kata tunggal (mufrad). Manakala jamaknya adalah "al-hikam" (al-Mu'jam al-Wasit, 1972, hlm. 190).

Secara istilahnya, perkataan "al-hikmah" juga diisyaratkan kepada perkataan yang sedikit tetapi mempunyai kandungan makna yang besar sepertimana definisi berikut:

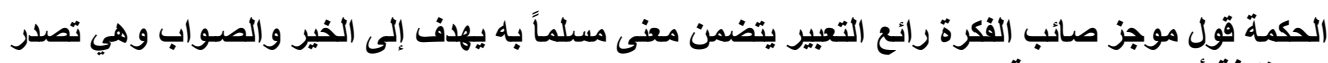
عن ثقافةٍ أو خبرةٍ وتجربةِة.

Maksudnya: "Kata-kata hikmat adalah kata-kata yang ringkas, mengandungi idea yang tepat, diungkapkan dengan ungkapan yang menarik, mengandungi makna yang baik dan bermatlamatkan sesuatu yang baik dan betul. la lahir daripada sesuatu pengtahuan kebudayaan yang tertentu ataupun sesuatu pengalaman" (Ahmad Muhammad Saqar, 1990, hlm. 57).

Kitab al-Hikam al-'Ata'iyyah merupakan sebuah karya dakwah yang mengandungi nilai-nilai tasawuf yang amat besar. la juga merupakan dasar kepada ajaran tasawuf Syeikh Ibn 'Ata'illah al-Sakandari dan peraturan serta ketetapan tarekat al-Syadziliyyah (Othman Napiah, 1992). Oleh yang demikian, walaupun beliau dianggap mahir dalam ilmu syariat, hebat dalam ilmu kesusasteraan dan kesenian bahasa, namun ketokohan beliau dilihat lebih menonjol dalam bidang pendidikan ilmu tasawuf.

Menurut Sulaiman Ibrahim (2005), isi kandungan kitab al-Hikam al'Ata'iyyah membicarakan beberapa persoalan pokok dalam ilmu tasawuf iaitu persoalan hakikat ketuhanan, etika sufi dan beberapa panduan serta kaedah penyucian jiwa (tazkiyat al-nafs). Persoalan-persoalan utama yang disentuh berhubung hakikat ketuhanan banyak tertumpu kepada hubungan intim yang seharusnya berlaku antara manusia dan Allah, makrifat Allah, tahap-tahap golongan yang mencari makrifat Allah dan lain-lain. Sementara persoalan etika sufi, isu-isu pembersihan jiwa dan nafsu (tazkiyat al-nafs) pula difokuskan kepada kepentingan seorang hamba yang salik untuk menyucikan nafsunya daripada kekotoran dosa dan maksiat, pemurnian akhlak daripada akhlak tercela kepada akhlak terpuji, membicarakan keajaiban-keajaiban hati dan nafsu, persoalan zikir dan 'uzlah yang menjadi wasilah utama ke arah (tazkiyat al-nafs) dan lain-lain. la juga merangkumi munajat ketuhanan yang banyak menyentuh hati yang termuat dalam bahagian ketiga dalam kitab al-Hikam al-'Ata'iyyah (Sulaiman Ibrahim, 2005).

Secara umumnya kandungan kitab tersebut merangkumi sekelompok teori dan pemikiran yang sebahagiannya berbentuk sufi, falsafah, figh dan masalah ilmu 
kalam. la dianggap sebagai sebuah kitab yang mempunyai keistimewaan kerana struktur kalimatnya yang bersastera tinggi. Selain itu juga, kedalaman makrifat yang dituturkan melalui kalimat-kalimatnya yang ringkas dan bermakna adalah merupakan hasil daripada sebuah kesucian tasawuf yang diterangi oleh al-Quran dan sunnah Rasulullah s.a.w.

\section{Keistimewaan Kitab al-Hikam al-'Ata'iyyah}

Menurut Shafie Abu Bakar (1990), kitab al-Hikam al-'Ata'iyyah telah disifatkan sebagai permata yang amat tinggi nilainya terhasil daripada lombong akal jiwa sufi yang bercirikan sifat-sifat keistimewaan tertentu. Ahmad ibn Muhammad ibn 'Ajibah al-Hasaniy Ibn 'Ajibah (1983) menyifatkannya sebagai anugerah ladunniy (mawahib ladunniyyah) dan rahsia-rahsia rabbani (asrar rabbaniyyah). Ibn 'Abbad (t.t.) menyifatkan al-Hikam al-'Ata'iyyah sebagai sebuah karya yang kecil saiznya, tetapi agung ilmunya, mempunyai ungkapan puitis yang halus dan makna-makna yang elok terbilang.

Ahmad ibn Ahmad ibn Muhammad Ahmad Zarruq (1985) pula menyifatkannya sebagai satu kumpulan ungkapan yang jelas isyaratnya, tinggi manfaatnya, kandungan ilmu dan hikmatnya menyejukkan dada, mencergaskan fikiran, menarik pendengaran dan pemerhatian. la adalah suatu kumpulan ilmu yang bersepadu antara ilmu dan hikamnya serta bertautan huruf-hurufnya dengan kalamkalamnya. Ini semua adalah kerana kesemuanya memenuhi makna saling menyempurnakan antara satu sama lain. Maka didapati awalnya berkait rapat dengan penutupnya, malah setiap masalah yang dikemukakan di dalamnya merupakan penyempurnaan kepada masalah sebelumnya dan pendahuluan kepada masalah yang datang kemudiannya. Setiap babnya seumpama huraian kepada bab sebelumnya dan bab yang datang sebelumnya pula seumpama huraian kepadanya. Setiap hikmah atau kalimah sesungguhnya seumpama penyempurnaan atau mukadimah, sehinggakan isi kandungan di bahagian akhirnya pula seumpama permulaannya (Ahmad ibn Ahmad ibn Muhammad Ahmad Zarruq, 1985).

Menurut ulasan Abd al-Halim Mahmud, seluruh ungkapan Ahmad ibn Ahmad ibn Muhammad Ahmad Zaruq tersebut memberikan maksud betapa alHikam al-'Ata'iyyah ini mempunyai kesatuan tajuk yang amat hebat.

Oleh yang demikian, ungkapan dalam al-Hikam al-'Ata'iyyah itu akan membawa kepada dua makna, pertama membawa kepada makna zahir perkataan dan keduanya pula akan membawa makna yang lebih bersifat tersirat setelah diamati dan didalami. Dengan kata lain bahawa ungkapan yang terdapat di dalam alHikam al-'Ata'iyyah itu ialah sedikit perkataannya tetapi mempunyai kandungan makna yang besar di sebalik perkataan itu. Keistimewaannya terserlah sama ada dari sudut kesusasteraan, kesufian, akidah dan syariah.

Walau bagaimanapun, pengkaji berpandangan bahawa kitab al-Hikam al'Atā'iyyah masih tidak diberi tumpuan secara meluas oleh para pengkaji bahasa memandangkan ia lebih popular sebagai kitab tasawuf yang menjurus kepada sebuah ajaran akhlak dan dakwah. Oleh yang demikian, pengkaji merasakan bahawa adalah penting satu penelitian khusus dilakukan bertujuan mengkaji aspek keindahan bahasanya yang luar biasa serta kata dan maknanya yang saling 
mempunyai kaitan sehingga melahirkan ungkapan-ungkapan yang memukau hati dan perasaan pembaca. Dalam pada itu, kewujudan gaya bahasa jinās dan nilai estetikanya dalam kitab al-Hikam al-'Atā'iyyah menyerlahkan keindahan kalam dakwah Syeikh Ibn 'Ata'illah al-Sakandari. Hal ini dilihat menepati tujuan dakwah itu sendiri iaitu untuk mengajak para pembaca menghayati dan mendalami kandungan dakwah yang ingin disampaikan.

Penulisan dakwah yang disasarkan kepada masyarakat umum hendaklah tidak hanya sekadar "melepaskan batuk di tangga". Isi dakwah perlu ringkas dan jelas. Di sinilah letaknya peranan bahasa dalam penyampaian mesej dakwah yang diharapkan dapat meninggalkan impak yang baik terhadap para pembaca. Susunan bahasa memainkan peranan utama agar sebarang kupasan mengenai dakwah ditampilkan dengan gaya yang mampu menjadi halwa telinga. Walau bagaimanapun, sejauh manakah kandungan dakwah tersebut berupaya mengusik pintu hati manusia yang sentiasa amat mendahagakan bahan bacaan yang mampu mencorak pemikiran dan jiwa mereka sekiranya persoalan gaya bahasa tidak diambil perhatian. Oleh sebab itu, pendekatan dakwah Syeikh Ibn 'Ata'illah al-Sakandari iaitu dengan memasukkan elemen gaya bahasa jinās adalah satu pendekatan yang perlu dikaji dan diteliti.

\section{Objektif Kajian}

Berdasarkan permasalahan di atas, persoalan yang timbul adalah "Dari sudut nilai estetika, bagaimanakah keserasian lafaz gaya bahasa jinōs yang terdapat di dalam kitab al-Hikam al-'Ata'iyyah?" Bagi menjawab persoalan kajian di atas, maka kajian ini bermatlamat untuk menjelaskan nilai estetika keserasian lafaz jinās di dalam karya dakwah al-Hikam al-Atāiyyah.

\section{Metodologi Kajian}

Dalam menelusuri kajian ini, kaedah yang akan digunakan adalah bersifat deskriptif kualitatif (manhaj dirasah wasfiyyah). Kaedah ini adalah satu penelitian dan bukan eksperimen. la bermaksud untuk mengumpul informasi terhadap data-data yang dikenal pasti untuk dianalisis, iaitu gaya bahasa jinās dalam kitab al-Hikam al'Atā'iyyah. Kemudian, data yang dikumpul akan dianalisis berpandukan kepada nilai estetika al-jinas yang dinyatakan oleh Ali al-Jundi (1954) iaitu keserasian lafaz pada bentuknya sama ada secara keseluruhan ataupun sebahagiannya.

Jadual 1 menunjukkan pengklasifikasian kategori jinās yang mempunyai keserasian lafaz secara keseluruhan lafaz dan kategori jinās yang mempunyai keserasian lafaz secara sebahagian lafaz. 
Jadual 1

Nilai estetika keserasian lafaz mengikut kategori jinas

\begin{tabular}{ll}
\hline \multicolumn{1}{c}{ Nilai Estetika } & \multicolumn{1}{c}{ Kategori } \\
\hline 1. Keserasian lafaz pada bentuknya secara keseluruhan & jinās tām \\
& jinās muharraf \\
& jinās qalb \\
& jinās tashīf \\
& \\
2. Keserasian lafaz pada bentuknya secara sebahagian & jinās nāqis \\
& jinās isytiqāq \\
& jinās syibih isytiqāq \\
& jinās mudāri' \\
& jinās lāhiq \\
\hline
\end{tabular}

\section{Analisis Nilai Estetika Keserasian Lafaz jinas}

\section{Contoh Keserasian Lafaz secara Keseluruhan pada Bentuknya}

\section{jinās tām.}

Jinās Tām merupakan salah satu bentuk jinās yang mempunyai persepakatan lafaznya, tanpa jurang perbezaan pada rangkaian lafaz dan baris antara keduaduanya (Ali al-Jundi, 1954). Keserasian lafaz jinās tām dapat dilihat menerusi lafaz yang menyepakati dari segi jenis huruf, bilangannya, keadaan barisnya dan susunannya seperti contoh berikut:

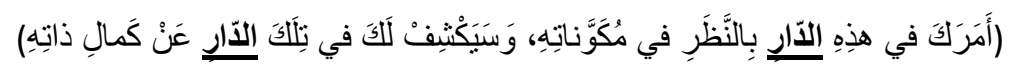

Terjemahan: "Allah menyuruhmu di dunia ini untuk memerhatikan alam ciptaanNya, dan kelak di akhirat Dia akan memperlihatkan kepadamu akan kesempurnaan Zat-Nya." (Hikmah 116)

Perkataan (الدّارَ) yang menunjukkan jinās tām terdapat pada hikmah yang ke 116 dengan maksud yang berbeza. Perkataan (الآّارَ) yang pertama bermaksud "dunia", manakala yang kedua bermaksud "akhirat". Pengulangan lafaz yang sama dan serasi tersebut memerlukan pembaca memberi perhatian terhadap maksud di sebaliknya.

Oleh yang demikian, pembaca dapat merasai bahawa ia menghasilkan kesan yang sangat hebat. Di sebalik hikmah yang diungkapkan, terdapat satu kekuatan luar biasa yang mampu menyingkap apa yang tersirat di sebalik hikmah tersebut. Pemilihan dua lafaz yang serasi secara keseluruhan tersebut telah menghasilkan satu pembentangan yang unik dan telah mengundang perhatian pembaca terhadap maknanya. Hubungan antara lafaz dan makna tersebut membawa kepada keperluan pembaca bertadabbur seterusnya meningkatkan penghayatan sewaktu pembacaan dilaksanakan. 
Pemilihan diksi yang tepat dalam hikmah tersebut dapat memberi peluang kepada pembaca untuk mengalami perasaan yang sama seperti pengarang dalam konteks menjiwai maksud yang dituju. Maka, kesesuaian diksi tersebut juga dapat menimbulkan imaginasi keindahan yang akhirnya membawa nilai kepuitisan dan nilai keindahan bahasa dalam hikmah.

\section{jinās muharraf.}

Menurut Ali al-Jundi (1954), jinās muharraf ialah lafaz yang menyepakati dari segi bilangan dan susunan huruf kedua-duanya, cuma sedikit berbeza pada barisnya sahaja. Keserasian lafaz jinās muharraf jelas kelihatan apabila lafaz yang menyepakati dari segi bilangan dan susunan huruf kedua-duanya, cuma sedikit berbeza pada barisnya. Contoh keserasian lafaz jinās muharraf boleh diperhatikan dalam hikmah berikut:

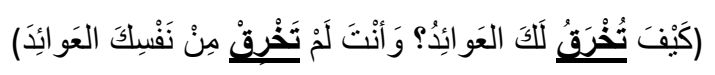

Terjemahan: "Bagaimana dapat dicarikkan kebiasaan (disingkapkan keajaiban) bagimu, sementara kamu belum mencarikan (mengubah) kebiasaan dirimu (yang buruk)." (Hikmah 127)

Dalam contoh hikmah di atas, terdapat keserasian dan kehalusan lafaz gaya bahasa jinās muharraf apabila berlakunya perbezaan makna dua lafaz dengan hanya dibezakan oleh sebutan baris sahaja. Perkataan (تَخْرَقِق

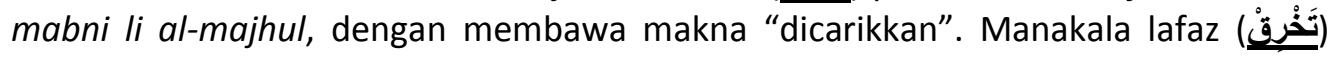
yang kedua adalah fi'il al-mudhari' majzum dengan membawa makna "kamu mencarikkan (mengubah) kebiasaan burukmu". Apabila pembaca menyebut perkataan tersebut dengan penghayatan, maka keseronokan dan kelazatan dalam menyebut lafaz yang berulang itu dapat dinikmati. Oleh sebab itu, Ali al-Jundi (1954) mengatakan nilai kemanisan jinās muharraf dapat dirasai di sebalik keserasian sebutan lafaz yang berulang berkenaan. Maka dengan pengulangan itu, menjadikan pembaca memberi tumpuan dan fokus terhadap maksud yang perlu difahami sebaiknya.

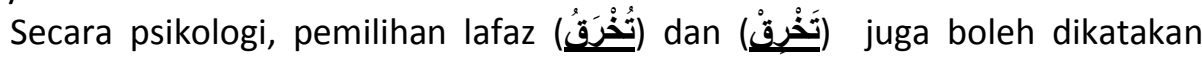
bukan sekadar tindak balas bahasa secara spontan (harakat al-'aliyat allughawiyyah), bahkan setiap jinās sebenarnya mesti mempunyai proses pemikiran atau perasaan dalaman yang mengawal imaginasi penutur dalam penggunaan sesuatu lafaz. Sehubungan itu, kehalusan jinās muharraf dalam lafaz tersebut dari sudut persembahannya dan kesan kepada pendengar dan pembaca adalah satu keistimewaan yang tidak dinafikan. Bahkan ia menimbulkan satu keindahan imaginasi dan membawa kepada kesempurnaan kepada penyampaian maksud.

Maka, dengan penggunaan jinās muharraf yang terdapat dalam hikmah ini, pengarang berjaya mengajak pembaca supaya berfikir bagaimana seseorang manusia itu mengharapkan sesuatu keajaiban dan kejayaan berlaku kepadanya, sedangkan dia tidak melakukan apa-apa tindakan ke arah itu. Hal ini selari dengan firman Allah s.w.t yang berbunyi : 


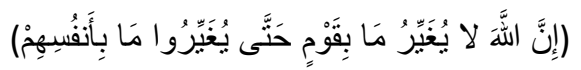

Maksudnya: "Sesungguhnya Allah tidak akan mengubah nasib suatu kaum kecuali kaum itu sendiri yang mengubah apa yang ada pada diri mereka"

(Al-Quran 13: 11)

\section{jinās qalb.}

Jinas qalb merupakan dua lafaz yang menyepakati rukun pada jenis huruf, bilangannya, bentuknya, namun ia berbeza pada kedudukan susunan hurufnya sahaja (Ali al-Jundi, 1954, hlm. 101). Keserasian lafaz jinās qalb pula ialah pada perbezaan dua lafaz yang menyepakati rukun pada jenis huruf dan bilangannya, namun ia berbeza pada kedudukan susunan hurufnya sahaja. Lantaran ia mempunyai persamaan pada jenis huruf dan bilangannya, maka keserasian tersebut berlaku pada bentuknya secara keseluruhan. Contoh boleh diperhatikan dalam hikmah yang ke 170 seperti berikut:

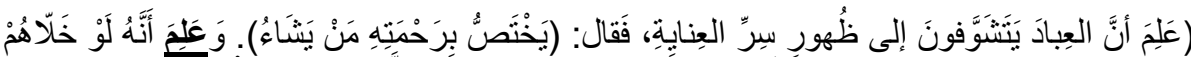

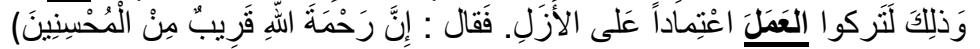

Terjemahan: "Allah mengetahui bahawa para hamba mendambakan terlihatnya rahsia pertolongan-Nya, maka Allah berfirman, Dan Allah menentukan siapa yang dikehendaki-Nya untuk diberi rahmat-Nya. Allah juga tahu, andaikan Dia membiarkan mereka begitu saja, maka mereka akan meninggalkan amalan kerana bersandar pada hukum (keputusan) azali semata-mata. Sehingga Allah berfirman, 'sesungguhnya rahmat Allah begitu dekat dengan orang-orang yang berbuat baik (muhsinin)." (Hikmah 170)

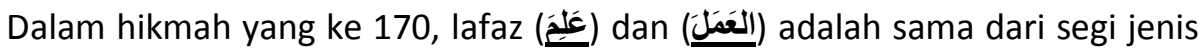

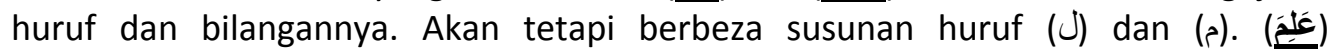
membawa maksud "mengetahui" dan (العَعَّل bermaksud "amalan". Di antara keduadua lafaz tersebut mempunyai perbezaan bilangan huruf disebabkan oleh (اللام ) (التعريفية). Namun begitu, sepertimana yang disepakati oleh para ulama balaghah bahawa (اللام التعريفية) tersebut tidak dikira sebagai penambahan huruf (Ali al-Jundi, 1954). Maka, kedua-duanya memperlihatkan lafaz yang serasi secara keseluruhannya. Hal ini kerana jenis dan bilangan huruf kedua-dua lafaz tersebut adalah sama secara keseluruhannya.

Secara literalnya, Lafaz (عَلَ) memberitahu bahawa "Allah mengetahui akan situasi hambaNya". Sementara lafaz (الَعَمَلَ) mengisyaratkan kepada "usaha amalan yang berterusan tanpa bersandar kepada keputusan azali (takdir) semata-mata". Hikmah ini memberi motivasi kepada manusia supaya terus berusaha menggandakan amalan kebaikan, kerana rahmat Allah sentiasa bersama orang yang melakukan amal kebaikan. Seruan motivasi tersebut diserikan lagi dengan dua lafaz yang sama serasi dari segi jenis huruf dan bilangannya. Justeru ia mencetuskan satu estetika lafaz yang sangat bernilai.

\section{jinās tashīf.}


Jinās tashîf didefinisikan oleh Ali al-Jundi (1954) sebagai lafaz yang mempunyai persamaan pada bentuk tulisan, tetapi berbeza pada sebutannya. Keserasian lafaz jinās tashîf menyerlahkan keindahan pada persamaan bentuk huruf dan tulisan, yang dibezakan oleh sebutannya.

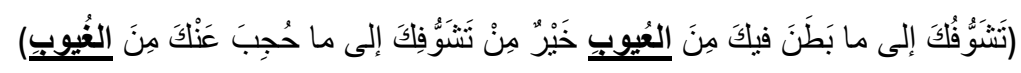

Maksudnya: "Usahamu untuk mengetahui aib-aib yang tersembunyi dalam dirimu adalah lebih baik daripada berusaha menyingkap perkara ghaib yang tersembunyi darimu." (Hikmah 32)

Dalam hikmah yang ke 32, lafaz antara (النُيوب) (الغُيوب) dan menyeru pembaca supaya memiliki kekuatan imaginasi agar melihat sifat sesuatu perkara dalam bentuk objek sebagaimana lukisan dan fotografi menerusi jiwa dan pemikiran. Sehubungan itu, kewujudan jinās tashîf dalam sesuatu ungkapan menampakkan kesenian, kedamaian jiwa, kelapangan hati pengarang sehingga mampu mencetuskan ukiran bentuk yang menarik perhatian. Ukiran bentuk lafaz (العُيوب) dan sememangnya serasi pada keseluruhan lafaznya dan mengagumkan para pembaca.

Dengan persamaan pada rupa bentuk sedemikian menyebabkan penggunaan jinās tashīf menghiasi keindahan fizikal hikmah sekali gus menyerlahkan suatu roh kepada keindahan kalam dakwah Syeikh Ibn 'Ata'illah al-Sakandari. Keindahan ini merujuk kepada ukiran bentuk lafaz yang kelihatan mempunyai kesenian yang dibawa oleh lafaz tersebut mempengaruhi psikologi pembaca dan memberikan suatu tenaga (hayawiyyat) dan kekuatan. Keadaan demikian lebih menyokong minat dan penghayatan pembaca serta berupaya menerima maklumat dengan berkesan. Justeru ia mencetuskan satu estetika lafaz yang sangat bernilai.

\section{Contoh Keserasian Lafaz secara Sebahagian pada Bentuknya}

\section{jinās nāqis.}

Jinās nāqis ialah dua lafaz yang menyerupai pada huruf dan barisnya, tetapi berbeza pada bilangan hurufnya (Ali al-Jundi, 1954). Keserasian lafaz jinās nāqis berlaku pada sebahagian bentuk lafaznya. Hal ini kerana jinās nāqis merujuk kepada perbezaan bilangan huruf disebabkan kekurangan bilangan huruf yang berlaku pada salah satu daripada dua lafaz berkenaan. Maka, keserasian lafaznya juga adalah pada sebahagian bentuknya. Contoh keserasian lafaz jinās nāqis boleh diperhatikan menerusi contoh hikmah berikut:

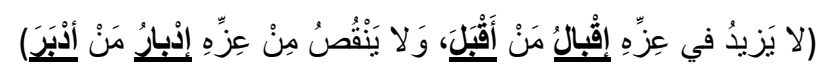

Terjemahan: "Tidaklah bertāmbah kemuliaan Allah kerana seseorang mendekatkan diri kepada-Nya, dan tidak berkurang kemuliaan-Nya karena seseorang menjauhiNya." (Hikmah 212) 
Dalam hikmah yang ke 212 seperti tersebut, terdapat dua pasangan lafaz yang mempunyai keserasian pada sebahagian bentuknya iaitu pertāma, antara lafaz

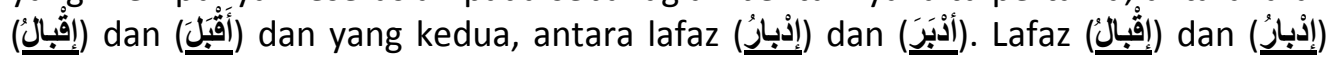
adalah masdar, masing-masing membawa makna berlawan iaitu "kedekatan dan

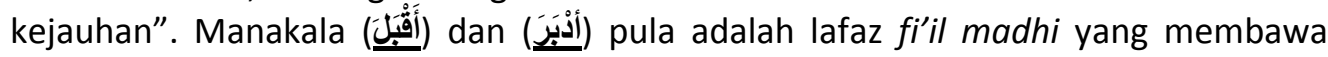
makna "mendekatkan dan menjauhkan". Apabila diperhatikan kepada penambahan huruf (alif) di pertengahan lafaz masdar tersebut menjadikan lafaz jinās nāqis serasi pada sebahagiannya sahaja.

Keserasian lafaz tersebut mempunyai unsur kaitan rapat dengan psikologi yang menyembunyikan keterpengaruhan dan mengambarkan emosi serta pemikiran pengarang. Ini kerana penggunaan jinās nāqis merupakan suatu roh yang ditiup oleh pengarang supaya ia menzahirkan satu ikatan lafaz yang mempunyai kaitan walaupun membawa makna lafaz yang berbeza. Justeru, ia memberi tenaga (hayawiyyat) dan kekuatan dalam jiwa pembaca. Dengan estetika keserasian lafaz tersebut, pengarang telah berjaya menzahirkan kaitan antara kedua-dua lafaz tersebut. Di sebalik kandungan hikmah di atas beliau telah berjaya menarik perhatian pembaca agar mendekatkan diri mereka kepada Allah s.w.t.

\section{jinās isytiqāq.}

Menurut Ali al-Jundi (1954), jinās isytiqāq ialah dua lafaz yang menyepakati pada huruf asalnya berserta maknanya yang asal. Keserasian lafaz jinās isytiqāq dapat diperhatikan menerusi hikmah yang ke 66 sepertimana contoh di bawah:

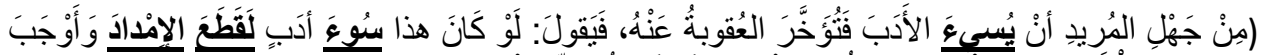

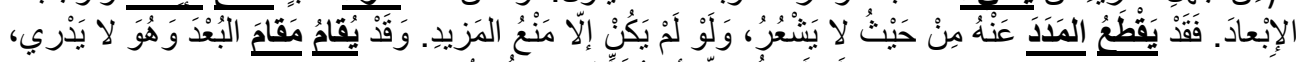

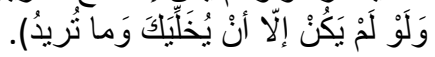

Terjemahan: "Di antara kejahilan para murid adalah, apabila ia beradab buruk (kepada-Nya) dan hukuman atasnya ditangguhkan oleh-Nya, maka ia berkata: seandainya ini adalah keburukan, maka pasti diputuskan bantuan (Allah) dan bahkan dijauhkan. Padahal, bantuan itu boleh jadi sudah dihentikan tanpa ia sedari, sekalipun hanya berupa tidak adanya tāmbahan bantuan baharu. Dan boleh jadi ia juga sudah dijauhkan tanpa ia mengerti, sekalipun hanya memberikan dirimu dan apa yang engkau inginkan (dari hawa nafsumu)." (Hikmah 66)

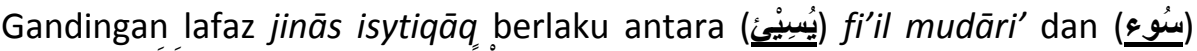

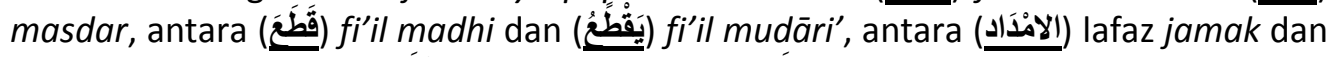

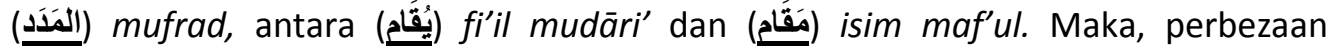
kedua-dua lafaz yang berubah daripada huruf asalnya berserta maknanya yang asal memperlihatkan keserasian tersebut berlaku secara sebahagian lafaz.

Jika diperhatikan contoh pembentukan jinās isytiqāq di atas, Syeikh Ibn 'Ata'illah al-Sakandari dilihat membentuk jinās dengan mudah sahaja, misalnyanya dengan menukarkan fi'il madhi kepada fi'il mudāri', fi'il kepada masdar, mufrad kepada jamak dan sebagainya. Dengan demikian, beliau berjaya memanipulasi huruf tertentu supaya menghasilkan satu keserasian lafaz tanpa mempunyai unsur-unsur bebanan (al-takalluf) yang keterlaluan. Hal ini kerana beliau sendiri terdidik daripada 
pentarbiahan pendokong bahasa yang tidak tunduk kepada keinginan untuk memonopoli kecemerlangan dan mengejar persaingan antara individu-individu lain. Apatah lagi berkarya untuk memberi kepuasan dengan tujuan kemegahan.

\section{jinās syibih isytiqāq.}

Ali al-Jundi (1954) mendefinisikan jinās syibih isytiqāq sebagai dua lafaz yang menyepakati sama ada secara sebahagian besar daripada hurufnya atau secara keseluruhannya di atas rupa paras seakan-akan kedua-duanya berasal daripada perkataan yang satu sebagaimana al-isytiqāq. Tetapi hakikatnya tidak begitu. Keserasian lafaz jinās syibih isytiqāq dapat diperhatikan dalam hikmah yang ke 68 sepertimana contoh di bawah:

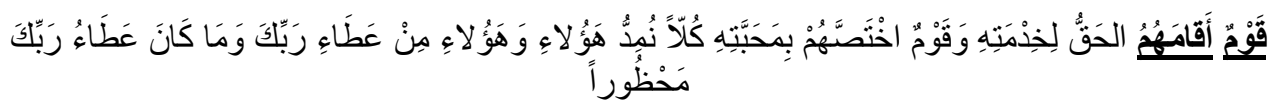

Maksudnya: "Ada sebahagian kaum yang Allah jadikan mereka untuk berkhidmat kepadaNya, dan sebahagian lainnya Allah istimewakan mereka dengan mencintaiNya. Kepada masing-masing golongan, baik golongan ini mahupun golongan itu, kami berikan bantuan dari kemurahan Tuhanmu. dan kemurahan Tuhanmu tidak dapat dihalangi." (Hikmah 68)

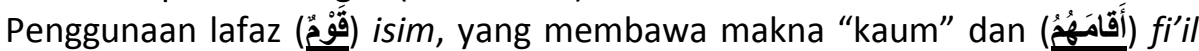
madhi, yang membawa makna "Allah dirikan mereka". Secara fizikalnya, kedua-dua lafaz tersebut mempunyai rupa paras seakan-akan berasal daripada perkataan yang satu. Sekali pandang seolah-olah kedua-dua mempunyai kaitan pada kalimah asalnya. Namun hakikatnya kedua-duanya tidak mempunyai kaitan dari sudut

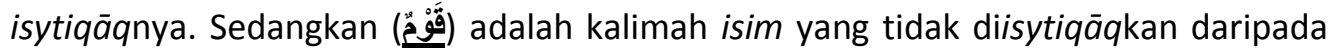
fi'il. Maka dengan rupa bentuk yang seakan-akan mempunyai kaitan sedemikian telah menghasilkan satu keserasian lafaz yang mengagumkan.

Mesej yang ingin dibawa oleh hikmah tersebut ialah supaya menjadi hamba yang berkhidmat kepada Allah s.w.t dan mempunyai kecintaan yang tinggi kepadaNya menerusi penawaran berbentuk motivasi kepada pembaca. Penggunaan jinās syibih al-isytiqāq dalam hikmah tersebut mempunyai nilai estetika yang cukup tinggi menerusi keserasian dua bentuk lafaz yang seakan-akan seperti berasal daripada satu perkataan yang sama. Di sini, pengarang dilihat berjaya menarik perhatian pembaca dan pendengar menerusi pemilihan lafaz yang mampu menarik perhatian dan memberikan suntikan motivasi ke arah menjadi hamba yang berkhidmat untuk Allah s.w.t.

\section{jinās mudāri'.}

Jinās mudāri' adalah menghimpunkan dua perkataan bersamaan jenis kecuali satu huruf sahaja yang tidak mempunyai jurang perbezaan antara keduanya dari segi makhraj, atau berdekatan, tanpa penambahan bilangan huruf. (Ali al-Jundi, 1954, hlm. 132). Keserasian lafaz jinās mudāri' ialah pada gandingan dua perkataan bersamaan jenis kecuali satu huruf sahaja yang berbeza. Oleh sebab perbezaan 
tersebut, maka kedua-dua lafaz jinās mudāri' berkenaan hanya mempunyai keserasian pada sebahagian bentuknya. Contohnya dapat dilihat menerusi hikmah berikut:

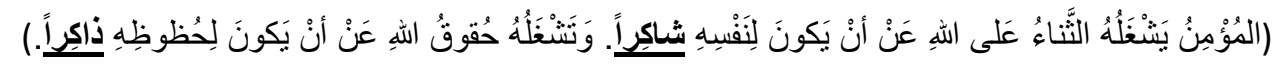

Maksudnya: "Seorang mukmin itu suka menyibukkan diri menyanjung Allah, sehingga tidak sempat untuk berterima kasih (memuji) kepada dirinya sendiri. Dan ia sibuk menunaikan kewajiban kepada Allah, sehingga ia lupa akan keuntungan untuk dirinya sendiri." (Hikmah 242)

Dalam hikmah yang ke 242, menzahirkan gaya bahasa jinās mudāri' antara lafaz (شاكِراً), bermakna "orang yang berterima kasih/memuji" dan (ذاكراً), bermakna "orang yang mengingati". Jinās mudāri' adalah merujuk kepada perbezaan huruf awalnya pada kedua-dua lafaz tersebut adalah antara (ش) dan (ذ) yang berdekatan pada makhraj hurufnya. Sebutan huruf kedua-duanya melibatkan kedudukan dan pergerakan lidah sahaja.

Jika diperhatikan antara huruf (ش) dan huruf (ذ), menurut Abdul Qadir Leong (2009), makhraj huruf (ش) keluar dari pertengahan daun lidah. Apabila diangkat ia akan menekan pada langit-langit keras, kemudian tekanan udara keluar daripadanya, maka terjadilah huruf (ش). Sementara huruf (ذ), hujung lidah yang dikeluarkan terletak di antara hujung gigi gunting atas dan hujung gigi gunting bawah, di mana tekanan hujung lidah pada hujung gigi gunting atas, maka terkeluarlah huruf (ذ). Kesimpulannya, walaupun antara huruf (ش) dan huruf (ذ) tidak mempunyai keserasian pada perbezaan bentuk huruf, tetapi sebutan kedua-dua huruf tersebut keluar daripada makhraj yang sama iaitu lidah (اللسان). Maka, dari sudut sebutannya menjadikan kedua-dua huruf tersebut juga seolah-olah mempunyai keserasian, lalu meringankan pada pergerakan lidah pembaca.

\section{jinās lāhiq.}

Menurut Ali al-Jundi (1954), jinās lāhiq adalah dua huruf yang berlaku perbezaan makhraj hurufnya yang ketara di antara kedua-duanya. Keserasian lafaz jinās lāhiq juga adalah pada sebahagian pada bentuknya seperti contoh di bawah:

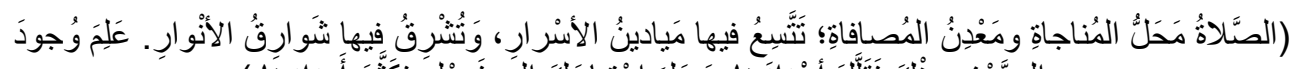

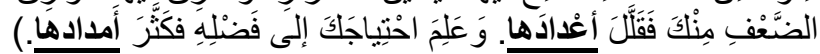

Terjemahan: "Solat merupakan tempat bermunajat serta sumber penyucian hati. Di dalam solat terbentang luas medan rahsia Allah, dan muncul darinya cahayacahayaNya. Allah tahu kelemahan dalam dirimu, maka Dia mengurangkan bilangan solatmu. Allah pun mengetahui hajat kamu pada anugrah-Nya, maka Dia melipatgandakan pahalanya (pahala solat)."

(Hikmah 252)

Dalam hikmah yang ke 252, perbezaan antara (أعُدادَها), bermakna "bilangan solat" dan (أَمدادها) , bermakna "ganjaran pahala solat". Menurut Abdul Qadir Leong 
(2009), makhraj huruf ( () terletak di antara dua bibir mulut. Apabila dua bibir dirapatkan secara ringan maka keluarlah huruf ( ( )). Sementara makhraj huruf $(\varepsilon)$ pula terletak di pertengahan rongga kerongkong hingga rongga mulut. Maka, jelas keduadua huruf tersebut mempunyai perbezaan yang ketara. Dengan perbezaan tersebut, keserasian lafaz tersebut secara jelas berlaku pada sebahagian bentuknya sahaja.

Dalam hikmah di atas, pengarang mendatangkan perbandingan bahawa hasil ganjaran rahmat Allah s.w.t yang diberikan kepada hambaNya yang solat adalah berlipat ganda, berbanding jumlah bilangan solat yang difardhukan hanya sedikit. Bandingan antara "ganjaran pahala solat" dan "bilangan solat" yang jauh ketara bandingannya seumpama ini, amat bersesuaian dengan penggunaan jinās lāhiq. Justeru, perbezaan tersebut membawa kepada pemerhatian sebutan lafaz dan kandungan maksud yang ingin disampaikan.

Secara kesimpulannya, keserasian lafaz secara keseluruhan lafaz terdapat pada empat kategori jinās iaitu; jinās tām, jinās muharraf, jinās qalb dan jinās tashīf. Manakala keserasian lafaz secara sebahagian lafaznya pula dapat dilihat pada lima kategori jinās iaitu; jinās nāqis, jinās isytiqāq, jinās syibih isytiqāq, jinās mudāri' dan jinās lāhiq. Susunan ungkapan hikmah dalam kitab al-Hikam al-'Atā'iyyah memiliki seni keserasian lafaz dengan menghimpunkan tiga perkara dalam masa yang sama iaitu: (i) Keindahan lafaz dan kalimah yang diguna pakai, (ii) Kehalusan makna dan (iii) Hubungan keserasian antara lafaz dengan maknanya. Maka, dengan demikian bahasa yang digunakan oleh Syeikh Ibn 'Ata'illah al-Sakandari mempunyai kesimbangan dari segi lafaz dan makna bersesuaian dengan konteks dan situasi di mana percakapan diungkapkan.

\section{Kesimpulan}

Penggunaan gaya bahasa jinās telah memainkan peranan penting dalam menyampaikan mesej dengan lebih berkesan berbanding dengan penggunaan gaya bahasa biasa terutāmanya dalam penulisan dakwah. Seperti yang telah dijelaskan, keserasian lafaz gaya bahasa jinās yang berlaku sama ada secara keseluruhan bentuknya ataupun secara sebahagiannya sahaja adalah sebuah kesenian bahasa yang bernilai dan bermakna. Maka, penggunaan gaya bahasa jinās di dalam kitab alHikam al-'Atā'iyyah keseluruhannya telah membuktikan sifat kreatif seorang pendakwah dan kemampuannya memanfaatkan unsur-unsur keindahan gaya bahasa jinās. Keindahan susunan lafaznya yang memikat hati, di samping merealisasikan format muzikal menerusi jinās yang dilukiskan di antara keserasian susunan rentak dan irama sesuai dengan maksud yang dituju. Natijahnya penulisan dakwah tersebut mampu menyampaikan maklumat dan isi kandungan dengan berkesan ke dalam jiwa pembaca. 


\section{Rujukan}

Al-Quran al-Karim.

Abdul Qadir Leong. (1999). Tajwid al-Quran rasm 'Uthmani. Kuala Lumpur, Malaysia: Pustaka Salam.

Ahmad ibn Ahmad ibn Muhammad Ahmad Zarruq. (1985)/(1405H). Syarah al-Hikam. Kaherah, Mesir: Dar al-Sya'b.

Ali al-Jarim, \& Mustafa Amin. (1979). al-Balaghah al-Wadihah. Beirut: Dar al-Ma'arif.

Ali al-Jundi. (1954). Fann al-Jinas: Balaghah wa Adab wa Naqd. Kaherah, Mesir: Dar al-Fikr al-'Arabiy.

Abd al-Qahir al-Jurnani. (1988). Asrar al-Balaghah. Beirut: Dar al-Kutub al-'Ilmiyyah.

Ahmad ibn Muhammad ibn 'Ajibah al-Hasaniy Ibn 'Ajibah. (1983). Iqaz al-Himam fi Syarhal-Hikam. Kaherah, Mesir: Dar al-Ma'arif.

Abdallah ibn al-Mu'taz. (1982). al-Badi'.Beirut, Lubnan: Dar al-Masirah.

Muhammad ibn Mukarram Ibn Manzur. (2003). Lisan al-Arab. Kaherah, Mesir: Dar al-Hadith.

Othman Napiah. (1992). Ajaran-ajaran tasawwuf ibn 'Ata illah al-Iskandari yang penting di dalam ktabnya al-Hikam. (Tesis ijazah sarjana yang tidak diterbitkan). Universiti Malaya, Kuala Lumpur, Malaysia.

Ahmad Muhammad Saqar. (1990), al-Adhwa' Fi al-Lughat al-'Arabiyyah, Kaherah: Nahdat Misr Li al-Tiba'at Wa al-Nashr Wa al-Tawzi'.

Shafie Abu Bakar. (1990). Hikam Melayu: Kajian falsafah dan etika. (Tesis doktor falsafah yang tidak diterbitkan). Universiti Kebangsaan Malaysia, Bangi, Malaysia.

Sulaiman Ibrahim. (2005). Manhaj dakwah al-Syaykh Ibn 'Ata' Allah al-Sakandariy dan pengaruhnya di Malaysia. (Tesis doktor falsafah yang tidak diterbitkan). Universiti Malaya, Kuala Lumpur, Malaysia 